\title{
8. TERTIARY PELAGIC OOZE ON ITA MAITAI GUYOT, EQUATORIAL PACIFIC: DSDP SITES 200 AND 201
}

\author{
The Shipboard Scientific Party ${ }^{1}$
}

\section{SITE DATA-SITE 200}

\section{Occupied: 27 Oct 1971}

Position: Summit of Ita Mai Tai Guyot lat $12^{\circ} 50.2^{\prime} \mathrm{N}$

long $156^{\circ} 47.0^{\prime} \mathrm{E}$

Water Depth: 1469 meters

Number of Cores: 10

Total Penetration: 132 meters

Deepest Unit Recovered: Early Eocene globigerina sandstone near base of upper transparent layer.

Main Results: The acoustically transparent layer which caps Ita Mai Tai Guyot consists of early Eocene to Quaternary winnowed foraminiferal ooze. Basalt fragments in the ooze suggests that the volcanic foundations outcrop in the vicinity.

\section{SITE DATA-SITE 201}

Occupied: 28 Oct 1971

Position: Summit of Ita Mai Tai Guyot lat $12^{\circ} 49.9^{\prime} \mathrm{N}$

long $156^{\circ} 44.6^{\prime} \mathrm{E}$

Water Depth: 1554 meters

Number of Cores: None

Total Penetration: 96 meters

\section{BACKGROUND}

The immediate reason for drilling Sites 200 and 201 was the state of repair of the crown block which the drillers were unwilling to use on a deep-water hole until it was inspected or repaired. Since no repair parts were aboard the ship, it seemed a strong possibility that an inspection would lead to the cancelling of all further drilling on Leg 20 . However, the drillers were willing to use the block on shallow-water holes, less than 2,000 meters. Thus, the guyots at the eastern end of the Caroline Abyssal Plain became attractive targets. If the tuff found at total depth at Site 199 represents the final eruption of the volcanics which form the base of these guyots, then the results from

\footnotetext{
${ }^{1}$ Bruce C. Heezen, Lamont-Doherty Geological Observatory; Ian D. MacGregor, University of California, Davis; Helen P. Foreman, Oberlin College; George Forristall, Eidgenössische Technische Hochschule, Zürich; H. Hekel, Queensland Geological Survey, Brisbane; Reinhard Hesse, Technische Hochschule, Munich; Robert H. Hoskins, New Zealand Geological Survey, Lower Hutt; E. John W. Jones, University College, London; Ansis Kaneps, Scripps Institution of Oceanography, La Jolla; Valeri A. Krasheninnikov, Academy of Sciences, Moscow; Hakuyu Okada, Kagoshima University, Japan; Michael H. Ruef, Washington Department of Ecology, Olympia.
}

the guyots might be combined with the incomplete Hole 199 to construct a history of the area. If the Paleocene limestones of Site 199 represent relatively deep water carbonates deposited as the Equator passed the site, then there might be a similar sequence of beds on the guyot which might serve as a further guide to the paleotectonic history of the area. It was with such questions in mind that the drilling of the guyots seemed to offer an attractive although enforced alternative to deep-sea drilling.

The location and bathymetry of Sites 200-201 are shown in Figures 1 and 2, respectively, and a seismic profile across Site 200 is given in Figure 3.

\section{OPERATIONS}

\section{Site $\mathbf{2 0 0}$}

Ita Mai Tai Guyot was approached from the northwest. Leaving the Caroline Abyssal Plain, the bottom rose steadily until at a depth of 1479 meters the shoulder of the table mount was reached. Sediment thickness apparently sufficient to allow spudding-in was found after a brief investigation. The beacon was dropped on the western part of the guyot top at 2200 on 26 October. The hole was spudded-in at 0545 on 27 October and continuous coring began at the mud line (Table 1). This program continued until 1315 on 27 October when the string began to stick in the hole.

The string was raised to the mud line at $1445-27$ October and Hole 200A spudded-in at 1530 on 27 October and drilled back to 65 meters where a core was attempted, to fill in an interval missed in Hole 200. The second core, taken at 132 meters, led to a stuck pipe. After working the pipe from 1830 to 1930 , the pipe came free and was pulled above the mud line and Site 200 abandoned at 2015 on 27 October 1971.

\section{Site 201}

The ship was moved from Site 200 to Site 201 with the string hanging 200 meters above the bottom. The ship began steaming west from Site 201 at 2015 on 27 October, making about $1 \mathrm{knot}$. The objective was to find a site where the upper transparent ooze was 50 to 75 meters thick. The seismic reflection record obtained when approaching Site 200 had indicated that such a locality could be found. However, it was not possible to run the seismic profiler at such slow speeds, and thus, the site was picked on the basis of water depth and the assumption, which proved incorrect, that the sediment thickness would be the same at that depth as at that earlier observed. After the beacon was dropped on site, a seismic record was obtained which indicated approximately 150 meters of upper transparent layer. Having already placed a beacon, it was decided to 


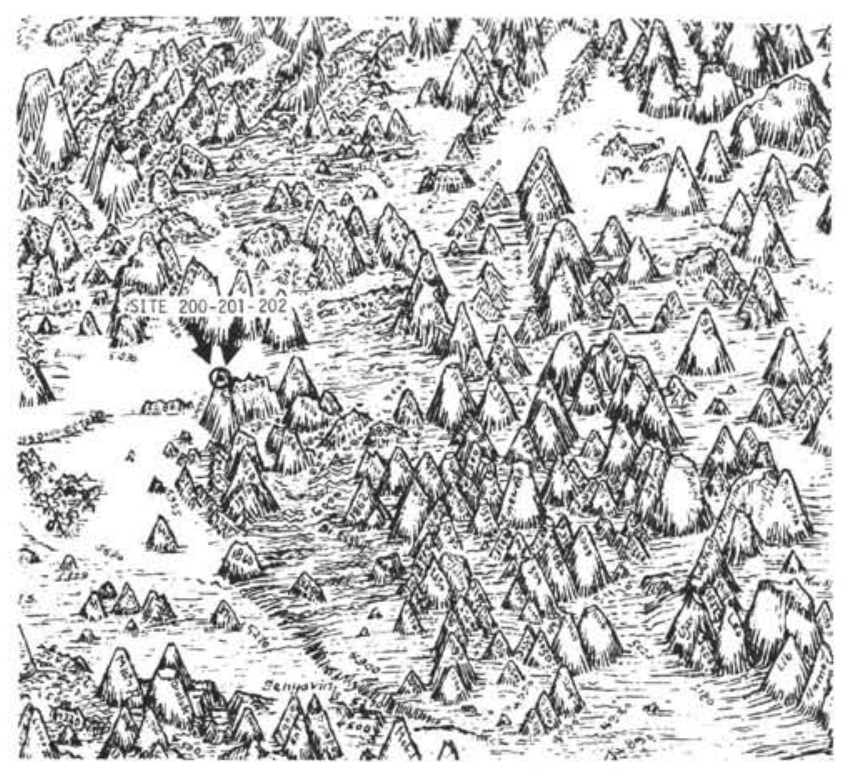

Figure 1. Location of Sites 200-201.

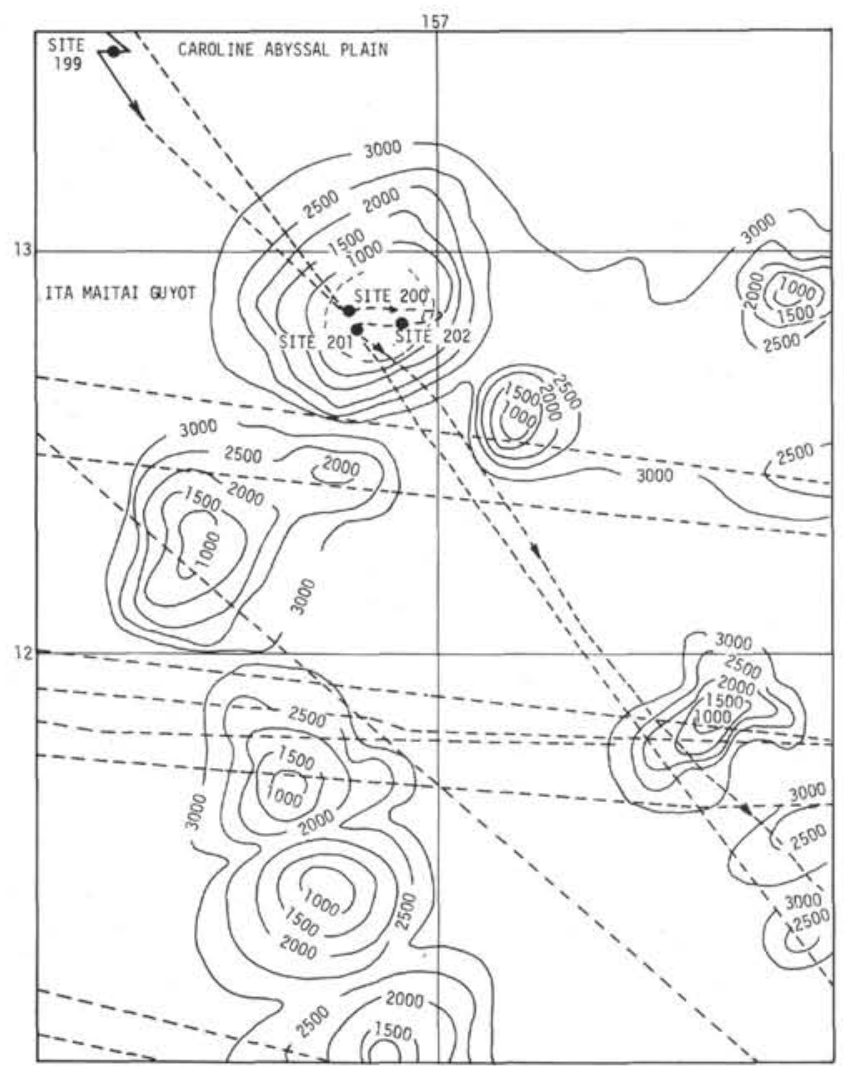

Figure 2. Bathymetry in the vicinity of Sites 200-201 (based on various sounding lines). Contour interval 100 tau $(1 \mathrm{tau}=1 / 400 \mathrm{sec})$.

attempt to drill a hole. Hole 201 was spudded-in at 0015 on 28 October. At about 120 meters, the same erratic weights which had previously indicated sticking at Site 200 were observed, and it was concluded that over the few thousand meters distance from Site 200 to 201 the lower

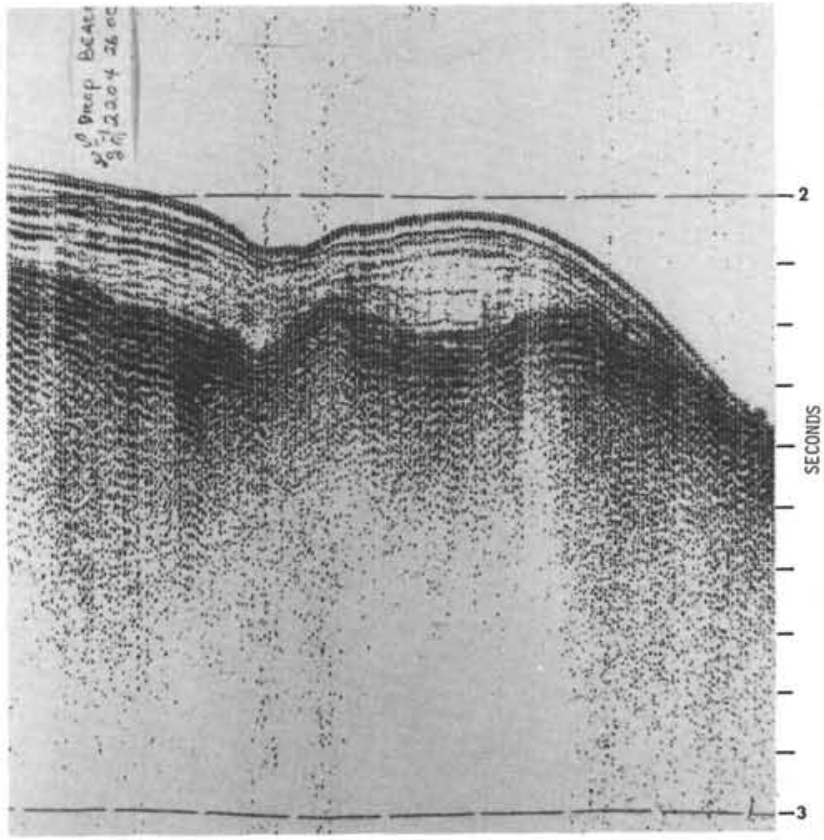

Figure 3. Glomar Challenger seismic profile across Ita Maitai Guyot.

foraminiferal sand retained its unfavorable drilling characteristics. Site 201 was abandoned at 0115 on 28 October without attempting to core. The drilled section at Site 200 is shown in Figures 4 and 5.

\section{NATURE OF THE SEDIMENTS-SITE 200}

Sediments were obtained at each of ten coring attempts in the section above the major reflector at 0.17 second below bottom on the seismic profile; the top 76 meters were cored continuously. Recovery was approximately 35 meters out of the total 95 meters of cored interval. All samples are thoroughly disturbed and very watery.

The succession above the major reflector appears to be uniform in composition, consisting of a nannofossil-bearing foraminiferal ooze which is pale orange, white, or pinkish gray in color. The content of acid-insoluble material is less than 1 percent and consists of small grains of plagioclase feldspar and fish teeth. The cored section ranges in age from early Miocene to Quaternary. Additionally, early Eocene was found in the core catcher of Core 2 of Hole 200A.

\section{BIOSTRATIGRAPHIC SUMMARY-SITE 200}

Pleistocene to early Eocene sediments were recognized at this site. All cores recovered consisted of soft nannofossil-bearing foraminiferal oozes containing abundant moderate to well-preserved foraminifera and nannofossils. Extremely rare well-preserved Radiolaria were found only in Hole 200, Core 1, and no diagnostically significant Radiolaria were recognized. Reworked planktonic foraminifera from the middle and early Eocene were found in all cores except Core 9 (85.5-95 meters). There was no indication of nannofossil reworking. 
TABLE 1

Coring Summary, Holes 200, 201

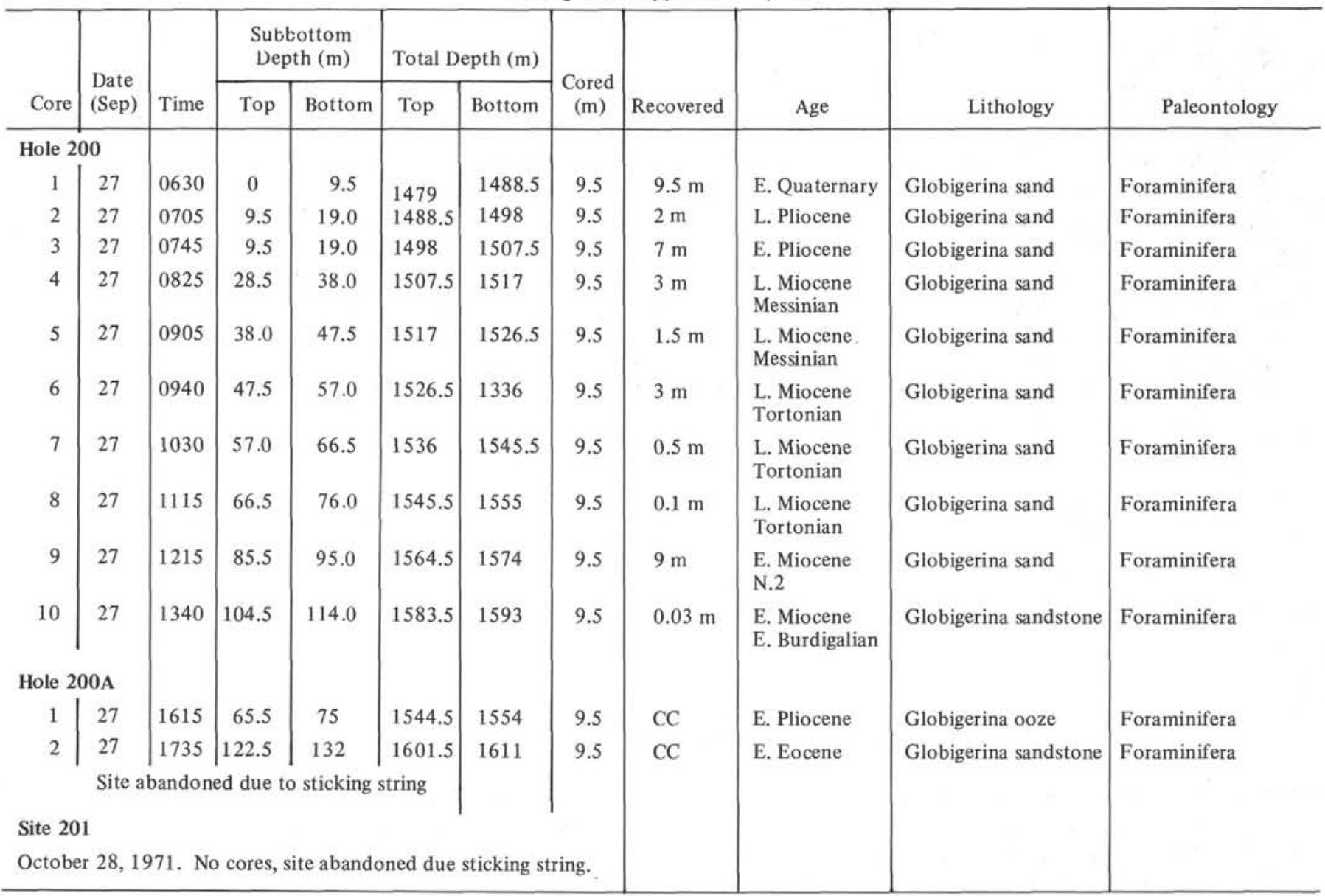

Note: Mudline is at 1479 meters.

Hole 200 penetrated 114 meters of winnowed foraminiferal ooze, representing an apparently continuous sequence from Pleistocene to early Miocene with an average sedimentation rate of 6.7 meters per million years. There was no recovery from the probable middle Miocene sediments in the interval 66.5 to 76.0 meters (Core 8). Cores 1 to 4 were very watery and likely to be mixed, and uphole contamination was found in all cores.

Core 1: Nannofossil evidence indicates that most of the Pleistocene is represented with the Emiliana huxleyi Zone

HOLES 200, 201
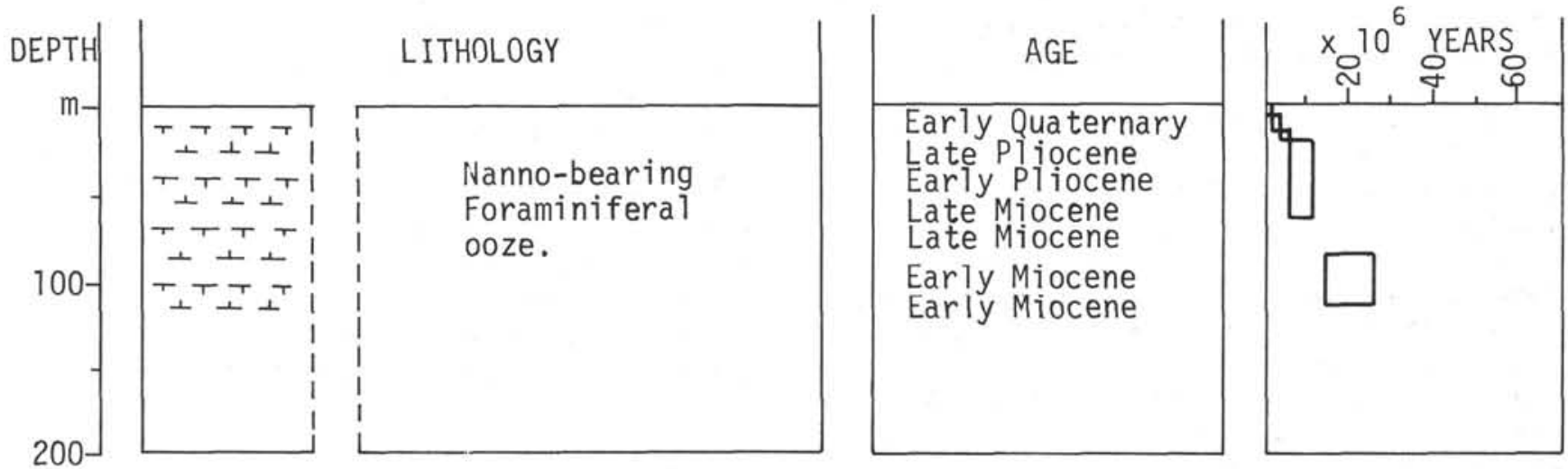

Figure 4. Stratigraphy of Site 200. 


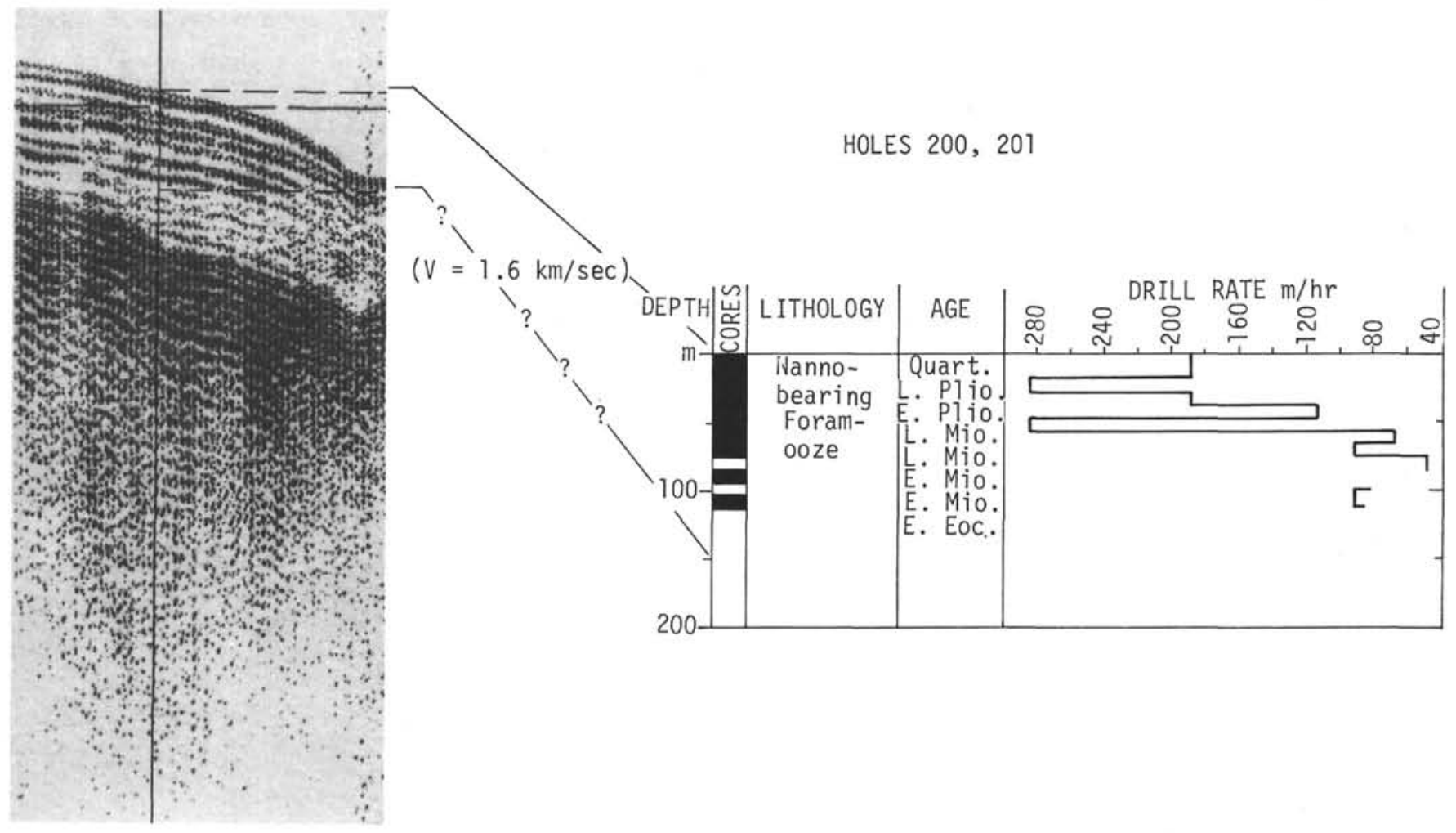

Figure 5. Correlation of drilled record at Site 200 with seismic profile.

present in Section 1, Gephyrocapsa oceanica Zone and $G$. caribbeaniaca Subzone in Sections 2 through 5 and the Emiliana annula Subzone in the core catcher. Foraminifera indicate the Globorotalia truncatulinoides Zone (N.22 of Blow).

Core 2: Discoaster pentaradiatus and D. tamalis subzones are represented, indicating a late Pliocene age for this core. Foraminifera of the Globorotalia tosaensis Zone (N.21 of Blow) are present.

Core 3: Foraminifera of the Sphaeroidinella dehiscensGloboquadrina altispira Zone (N.19 of Blow) and nannofossils of the Discoaster tamalis, D. asymmetricus, and Sphenolithus neoabies subzones indicate an early Pliocene age for this core.

Core 4: This core is also early Pliocene, indicated by the presence of the Ceratolithus rugosus Subzone and the Triquetrorhabdulus rugosus-Ceratolithus amplificus zonal interval of nannofossils and foraminifera typical of the Sphaeroidinellopsis subdehiscens-Globorotalia tumida Zone (N.18 of Blow).

Core 5: Late Miocene foraminifera of the Globorotalia plesiotumida Zone and nannoplankton of the Triquetrorhabdulus rugosus-Ceratolithus amplificus interval are present.

Core 6: Nannofossils of the Discoaster neorectus Subzone and foraminifera of the Globorotalia acostaensisG. merotumida Zone (N.16 of Blow) are present and indicate late Miocene.

Core 7: Late Miocene foraminifera, transitional between zones N.15 and N.16 of Blow, were recognized. Nannoplankton of the Discoaster bellus Subzone are present.
Core 8: No recovery.

Core 9: Foraminiferal oozes at the top of this core correspond to the basal part of the middle Miocene N.9 of Blow, Orbulina suturalis-Globorotalia peripheroronda Zone. The remainder of the core contains typical Globigerinoides sicarnus-Globigerinatella insueta Zone foraminifera (N.8 of Blow). Nannoplankton zones present are the Sphenolithus heteromorphus and Helicopontosphaera ampliaperta zones.

Core 10: An early Miocene age is indicated by the presence of the Helicopontosphaera ampliaperta Zone of nannoplankton. Foraminiferal assemblages are similar to those of N.6-N.7 of Blow and include Globigerinita stainforthi, Globoquadrina praedehiscens, Globigerinoides bisphericus and Globoquadrina langhiana.

Only two cores were recovered in Hole 200A. Early Pliocene nannoplankton and foraminifera were recovered in Core 1 from the interval 65.5 to 75 meters. The same depth was late Miocene in Hole 200, which suggests that the recovered material may be cavings. Core 2 (122.5-132 meters) contains an indurated foraminiferal sandstone of early Eocene age in which nannoplankton are rare. Extrapolation of the Neogene sedimentation rates of Hole 200 suggests that there is either a sedimentation gap between the early Miocene and early Eocene or a marked reduction in the sedimentation rate, resulting in a condensed sequence.

Biogenic components found in Site 200 cores are summarized below. Coring was not attempted at Site 201.

\section{Core 1:}

Foraminifera: Abundant planktonic foraminifera: Globorotalia truncatulinoides, $G$. tumida, G. humerosa, $G$. 
cultrata, G. inflata, G. crassaformis, Sphaeroidinella dehiscens, Pulleniatina obliquiloculata, Globigerinoides conflobatus, $G$. fistulosus, G. rubra, $G$. sacculifer, Orbulina universa, Candeina nitida, and Hastigerina siphonifera. Pleistocene; Zone N.22.

Nannofossils: Here a good recovery of five sections seems to represent most of the Pleistocene. In Section 1, presence of the Emiliania huxleyi Zone is established by examination with the electron microscope. Sections 2 to 4 have only been studied with the light-microscope and represent the Geophyrocapsa oceanica Zone. Section 5 represents the Geophyrocapsa caribbeanica Zone, and in the core catcher sample, the Emiliania annula Zone has been found. Cyclococcolithina aff. $C$. macintyrei is persistent throughout this core. In Sections 1, 2, and 4, few specimens of Coccolithus pelagicus are present, possibly indicating colder periods.

Radiolaria: Extremely rare, good Radiolaria. No stratigraphically significant species were recognized.

\section{Core 2:}

Foraminifera: Abundant and diverse planktonic foraminifera: Sphaeroidinella dehiscens, Pulleniatina obliquiloculata, Globorotalia tumida, G. ungulata, G. humerosa, G. cultrata, G. inflata, Globigerinoides fistulosus, $G$. conglobatus, and Candeina nitida together with rare specimens of Globorotalia tosaensis and G. multicamerata.

Late Pliocene; Zone N.21 (basal part, or transition to Zone N.20).

Nannofossils: In Sections 1 and 2, the late Pliocene Discoaster pentaradiatus Subzone of the Discoaster brouweri Zone is found with signs of uphole contamination in Section 1. The core catcher sample still contains Discoaster tamalis, indicating the Discoaster tamalis Subzone. Scyphospaera spp., Discoaster surculus., pentaradiatus, and D. brouweri are common forms.

Radiolaria: none.

Core 3:

Foraminifera: Assemblages of abundant and very diverse planktonic foraminifera: Sphaeroidinella dehiscens, Sphaeroidinella dehiscens, Sphaeroidinellopsis subdehiscens, Sph. seminulina, Globorotalia tumida tumida, G. humerosa, G. crassaformis, G. hirsuta, G. multicamerata, Globigerinoides conglobatus, Globigerina nepenthes, Candeina nitida, Globoquadrina altispira, $G$. dehiscens, Pulleniatina obliquiloculata. Early Pliocene; Zone N.19.

In Sections 1 and 2, Sphaeroidinellopsis spp., Globigerina nepenthes, and Globoquadrina altispira are very rare. Evidently, transition to Zone N.20.

Nannofossils: In Sections 1 and 2, the late Pliocene Discoaster tamalis Subzone is still represented. Sections 3 and 4 are assigned to the Discoaster asymmetricus Subzone and the core catcher sample represents the Sphenolithus neoabies Subzone of the early Pliocene. Here discoasters predominate over coccoliths in some samples, possibly indicating winnowing of the finer grain-size. The absence of Coccolithus pelagicus in this core may indicate deposition in a warmer environment.
Species of Scyphosphaera, especially Scyphosphaera globulata, are common.

Radiolaria: None.

\section{Core 4:}

Foraminifera: Assemblages of abundant planktonic foraminifera include Globorotalia tumida tumida, G. menardii, G. multicamerata, G. miocenica, G. margaritae, Globigerina nepenthes, Sphaeroidinellopsis seminulina, Sph. subdehiscens, Orbulina universa, Globoquadrina altispira, Globigerinoides obliquus extremus, Candeina nitida, Pulleniatina primalis, and very rare Globorotalia tumida plesiotumida. Upper Miocene; Messinian stage; Zone N.18.

Nannofossils: Sections 1 and 2 are assigned to the Ceratolithus rugosus Subzone of early Pliocene age as they include the overlap of the ranges of Ceratolithus rugosus and Ceratolithus tricorniculatus. Sections 3 and 4 could only be assigned to the interval between Triquetrorhabdulus rugosus Subzone and Ceratolithus amplificus Subzone (late Miocene) as no Triquetrorhabdulus rugosus was not found in our preparations. Ceratolithus bizzarus is present in this interval.

Radiolaria: none.

\section{Core 5:}

Foraminifera: Abundant planktonic foraminifera presented by Sphaeroidinellopsis seminulina, Sph. subdehiscens Globorotalia tumida plesiotumida, G. miocenica, $G$. menardii, G. margaritae, G. multicamerata, G. acostaensis, Orbulina universa, Globigerina nepenthes, Globigerinoides obliquus extremus, G. bollii, Candeina nitida, and Pulleniatina primalis. Upper Miocene; Messinian stage; Zone N.17.

Nannofossils: Section 1 and the core catcher sample are assigned to the interval between the Triquetrorhabdulus rugosus and Ceratolithus amplificus subzones (late Miocene) because of the occurrence of Ceratolithus tricorniculatus. The Discoaster quinqueramus Zone seems to be lost in a sampling gap. The abundant nannofossils include also Scyphosphaera spp., Reticulofenestra pseudoumbilica, Discoaster bellus, D. dilatus, and $D$. surculus.

Radiolaria: none.

\section{Core 6:}

Foraminifera: Planktonic foraminifera of the core catcher and Section 2 are represented by numerous Sphaeroidinellopsis seminulina, Sph. subdehiscens, Globorotalia cultrata, G. menardii, Globigerina nepenthes, Orbulina universa, Globoquadrina dehiscens, G. altispira, common Globigerinoides obliquus extremus, Globorotalia merotumida, rare $G$. lenguaensis, $G$. acostaensis, Candeina nitida. Upper Miocene, Tortonian stage; Zone N.I6.

Rare specimens of Globorotalia plesiotumida were found in Section 1. The age of these sediments: Messinian stage, Zone N.17 (but uphole contamination may take place on account of soupy character of oozes).

Nannofossils: Sections 1 and 2 and the core catcher sample are assigned to the Discoaster neorectus Subzone of the Discoaster neohamatus Zone (late Miocene), mainly because of the first common occurrence of Discoaster 
brouweri and the absence of Discoaster quinqueramus. Discoaster hamatus and Discoaster neohamatus are common components of this assemblage. The Abundant nannofossils include also Discoaster pseudorariabilis, $D$. bellus, D. dilatus and Sphenolithus abies.

Radiolaria: none.

\section{Core 7:}

Foraminifera: The following species of planktonic foraminifera are present in the core catcher: abundant Sphaeroidinellopsis subdehiscens, Sph. seminulina, Globierina nepenthes, Globoquadrina altispira, G. dehiscens, common Globorotalia menardii, G. cultrata, G. obesa, Orbulina universa, Globigerina bulloides, Globigerinoides obliquus, G. bollii, rare Globorotalia merotumida, $G$. acostaensis, $G$. lenguaensis, Candeina nitida praenitida, and Globigerina bulbosa. Upper Miocene; Tortonian stage; Zone N.15 (top) or N.16 (base).

Nannofossils: Only the core catcher sample has been recovered showing signs of uphole contamination. The main difference from Core 6 is that Discoaster brouweri is only represented as rare specimens. Discoaster bellus and Discoaster neohamatus are important components. Helicopontosphaera Kamptneri is unusually common in this sample. Late Miocene; Discoaster bellus Subzone of D. neohamatus Zone.

Radiolaria: none.

\section{Core 8:}

Foraminifera: None (mixture of Pliocene, upper and middle Miocene planktonic foraminifera-uphole contamination).

Nannofossils: Only the core catcher sample was recovered, and no interpretation is made because of the predominance of caved material.

Radiolaria: None.

\section{Core 9:}

Foraminifera: The assemblage of planktonic foraminifera of Section 1 consists of Orbulina suturalis, Globorotalia praemenardii, $G$. obesa, $G$. siakensis, $G$. peripheroronda, G. (Clavatorella) bermudezi, Sphaeroidinellopsis seminulina, and Hastigerina siphonifera. Middle Miocene; Zone N.9 (lower part).

All other sections (2-6) contain Praeorbulina transitoria, P. glomerosa, Globigerinoides bisphaerica, $G$. diminuta, G. mitra, G. trilobus, Globoquadrina dehiscens, G. altispira, G. langhiana, G. baroemoenensis, and Globigerinatella insueta. Lower Miocene; Burdigalian stage; Zone N.8.

Nannofossils: Good sediment recovery with all 6 sections has been made in this core. Discoasters, especially from the Discoaster deflandrei group, are common but show a high degree of recrystallization. Discoaster exilis, which should be typical for the Sphenolithus heteromorphus Zone, cannot be identified, probably because of the massive recrystallization. The disappearance of Helicoponthosphaera parallela and the first occurrence of a number of specimens of Cyclococcolithina macintyrei are used to differentiate the Sphenolithus heteromorphus Zone (Sections 1 to 5) from the Helicopontosphaera ampliaperta Zone below (Section 6 and the core-catcher). Helicopontosphaera ampliaperta itself could not be found. All samples are rich in well-developed Sphenolithus heteromorphus and are assigned to the $S$. heteromorphus Zone of early Miocene to earliest middle Miocene age.

Radiolaria: None.

\section{Core 10:}

Foraminifera: The core catcher includes sediments of two different types with foraminifera of different ages.

Soft calcareous oozes are characterized by numerous Globigerinoides bisphaerica, G. trilogus, G. subquadratus, Globoquadrina dehiscens, and $G$. altispira together with less abundant Praeorbulina glomerosa, Globigerinoides diminuta, and Globoquadrina langhiana. Lower Miocene; Burdigalian stage; Zone N.8.

Pieces of hard limestone contain numerous Globigerina bradyi, G. juvenilis, G. binaiensis, G. falconensis, Globigerinoides trilogus, common Globoquadrina baroemoenensis, G. altispira, rare Globigerinita stainforthi, and Globoquadrina praedehiscens. Lower Miocene; transition from Aquitanian to Burdigalian stages; Zone N.6 (upper part).

Nannofossils: Only the core catcher sample is available, indicating the Helicopontosphaera ampliaperta Zone (early Miocene) with massive occurrence of Spenolithus heteromorphus. Rare specimens of Braarudosphaera are present. Helicopontosphaera paralella characterizes this sample in the absence of the typical species.

Radiolaria: None.

\section{Core 1A:}

Foraminifera: Abundant Sphaeroidinella dehiscens, Sphaeroidinellopsis subdehiscens, Sph. seminulina, Pulleniatina obliquiloculata, Candeina nitida, Globorotalia tumida, $G$. crassaformis, G. humerosa, G. hirsuta, Globigerina nepenthes, Globoquadrina dehiscens, G. altispira, Globigerinoides conglobatus, G. ruber. Lower Pliocene (with reworked lower Eocene species-Globorotalia aragonensis, G. caucasica, Acarinina pentacamerata and uphole contamination-Pleistocene Globorotalia truncatulinoides).

Nannofossils: The nannofossil association with Ceratolithus rugosus must be caved, as in a similar depth (75 m) early Miocene is already represented in Hole 200.

Radiolaria: None.

\section{Core 2A:}

Foraminifera: Very rich assemblages of planktonic foraminifera consisting of numerous Globorotalia formosa, $G$. marginodentata, G. quetra, G. troelseni, G. wilcoxensis, $G$. apanthesma, $G$. lensiformis, Acarinina triplex, $A$. pseudotopilensis, A. soldadoensis, A. gravelli, $A$. decepta, A. broedermanni together with rare Globorotalia aragonensis, G. caucasica, G. marksi, G. naussi, Globigerina prolata, Chilogümbelina wilcoxensis. Lower Eocene; the Globorotalia formosa formosa Zone (uppermost part).

Nannofossils: Only a few nannofossils could be recovered from the well-sorted globigerina sands. Uphole contamination cannot be excluded due to the nature of the sediment. The discoaster seem to be less recrystallized 
and contrast sharply with those which are caved from the Miocene part of the section. Only a rather broad age-interpretation (early to middle Eocene) is given because of the lack of the typical discoasters, which would be expected in the Eocene. The rather long ranging Coccoliths include Lophadolithus spp, Chiasmolithus grandis, Chiasmolithus consuetus, Cyclococcolithina lusitanica and Coccolithus cf. crassus. The discoasters include Discoaster cf. barbadiensis and atypical Discoaster cf. lodoensis in small numbers.

Radiolaria: None.

\section{PHYSICAL PROPERTIES-SITE 200}

No physical properties summary can be presented for Site 200 , since, except for a few tiny lumps, all cores recovered were much too liquid and dilute for meaningful measurements to be made. One core was run through the GRAPE device, but the results are almost certainly valueless because the core was greatly disturbed during drilling and then artificially compacted by settling in the laboratory.

\section{CONCLUSIONS}

The winnowed foraminiferal ooze (or perhaps more properly foraminiferal sand) indicates a delicate balance between deposition and erosion throughout post-Paleocene time. It is not surprising to find winnowed foraminiferal ooze on the crest of seamounts, but Ita Mai Tai Guyot possesses a thicker section than one might expect to find. Certainly, the seismic profiler shows an exceptionally transparent and relatively thick acoustic layer. Many of the mid-Pacific mountains have thin sediment caps, but several which have been investigated near Wake Island do not, and the guyots off Japan which have been investigated have little or no sediment capping. Thus, the exceptionally thick cap on Ita Mai Tai may relate to exceptional conditions which may prevail or may have prevailed here. As a practical conclusion for future seamount drilling, the attractive spud-in thickness must be treated with skepticism, for sticking pipes should be expected in sand, and the thicker the sand the more formidable the barrier.

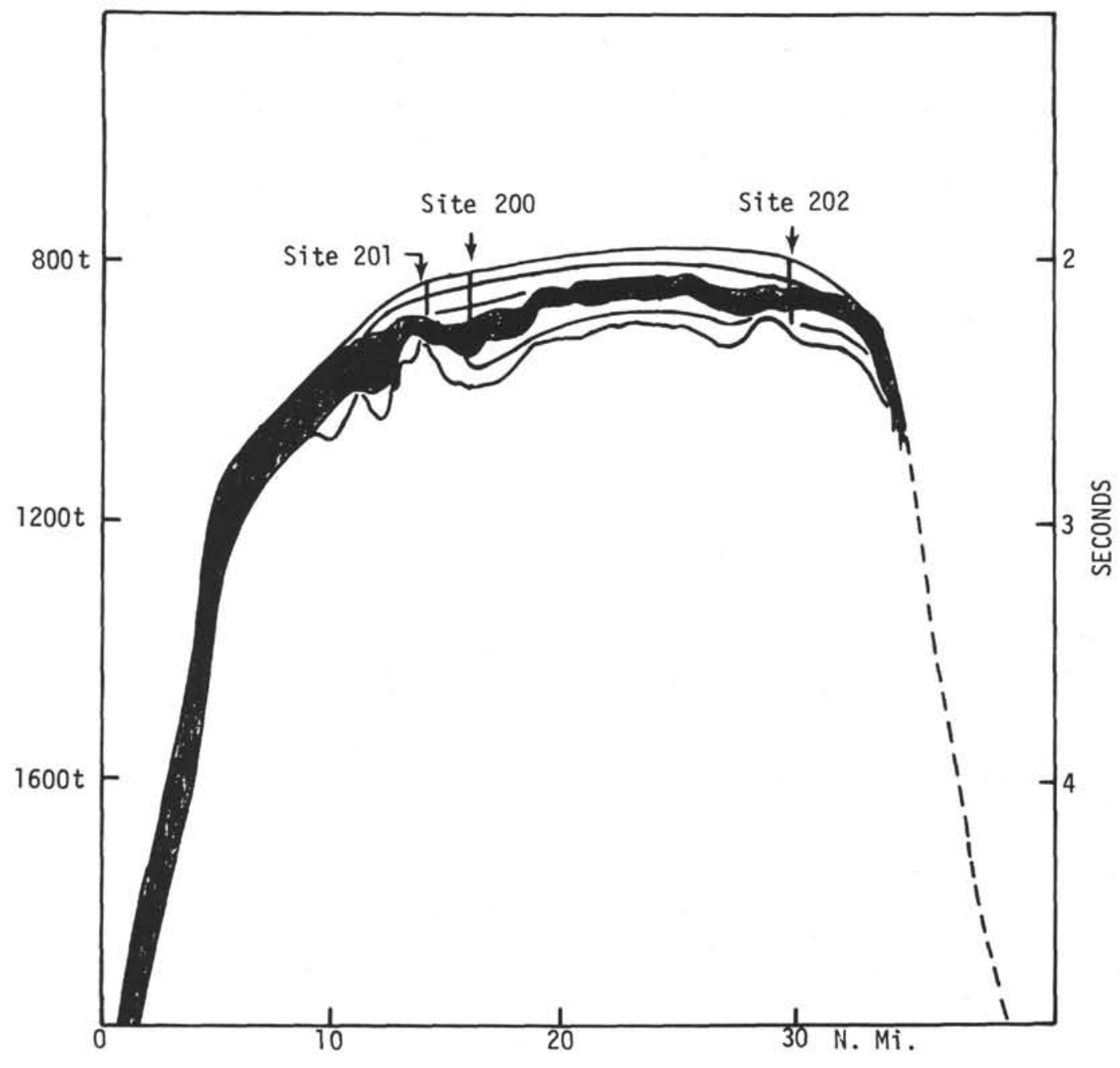



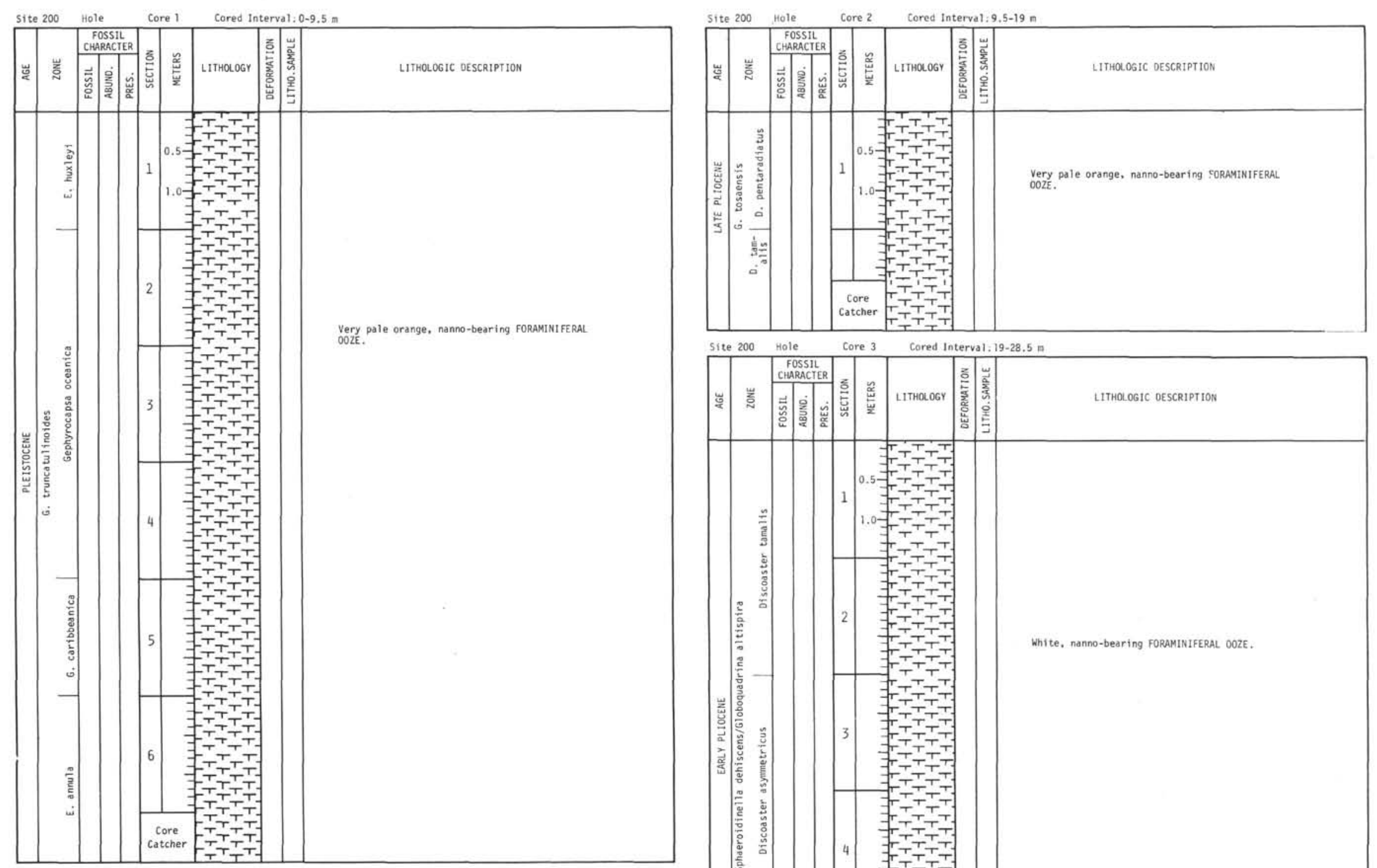

Explanatory notes in Chapter ?

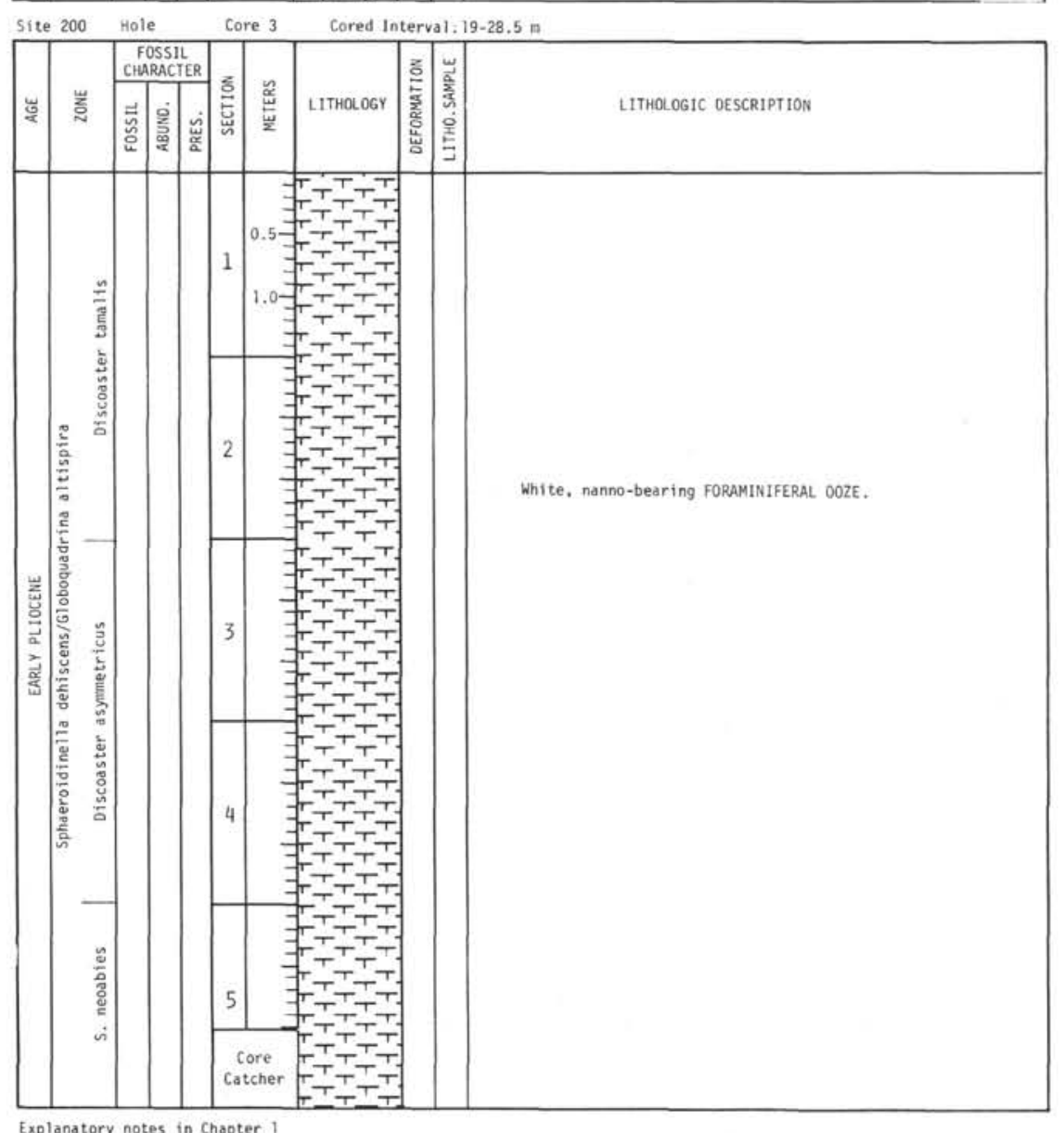


Site 200 Hole Core 4 Cored Interval: $28.5-38 \mathrm{~m}$

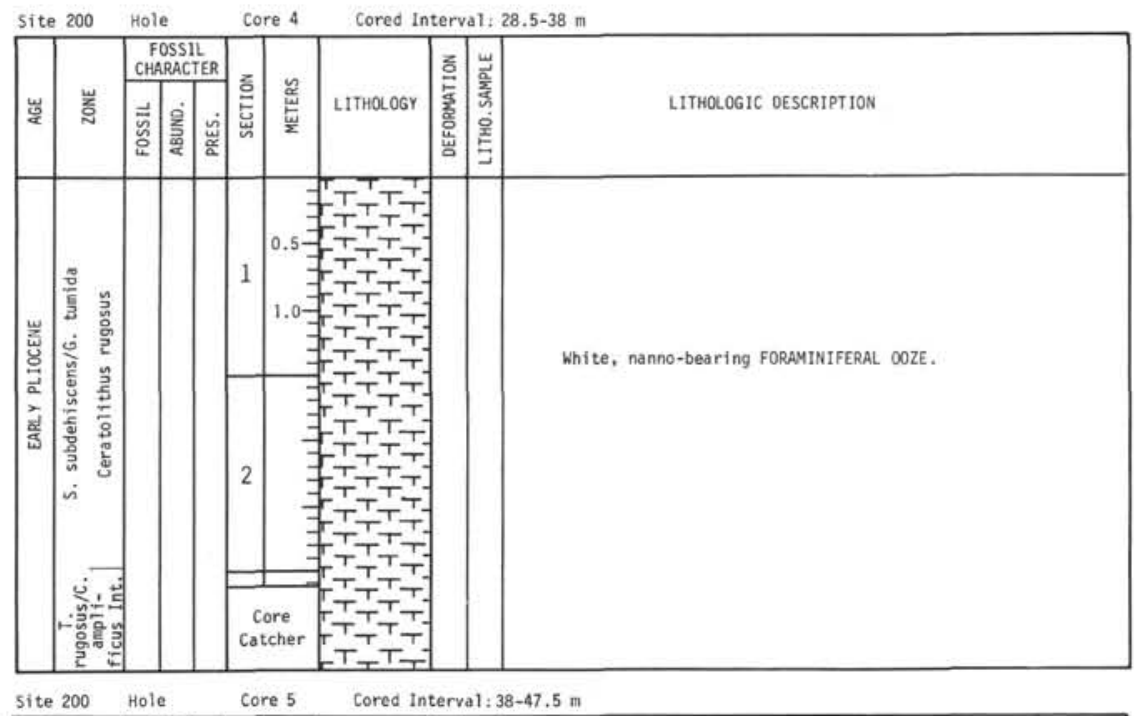

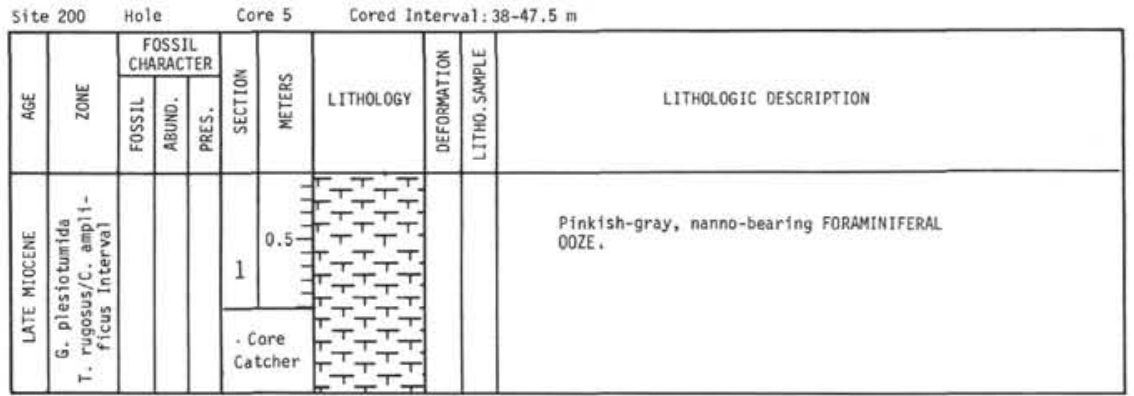

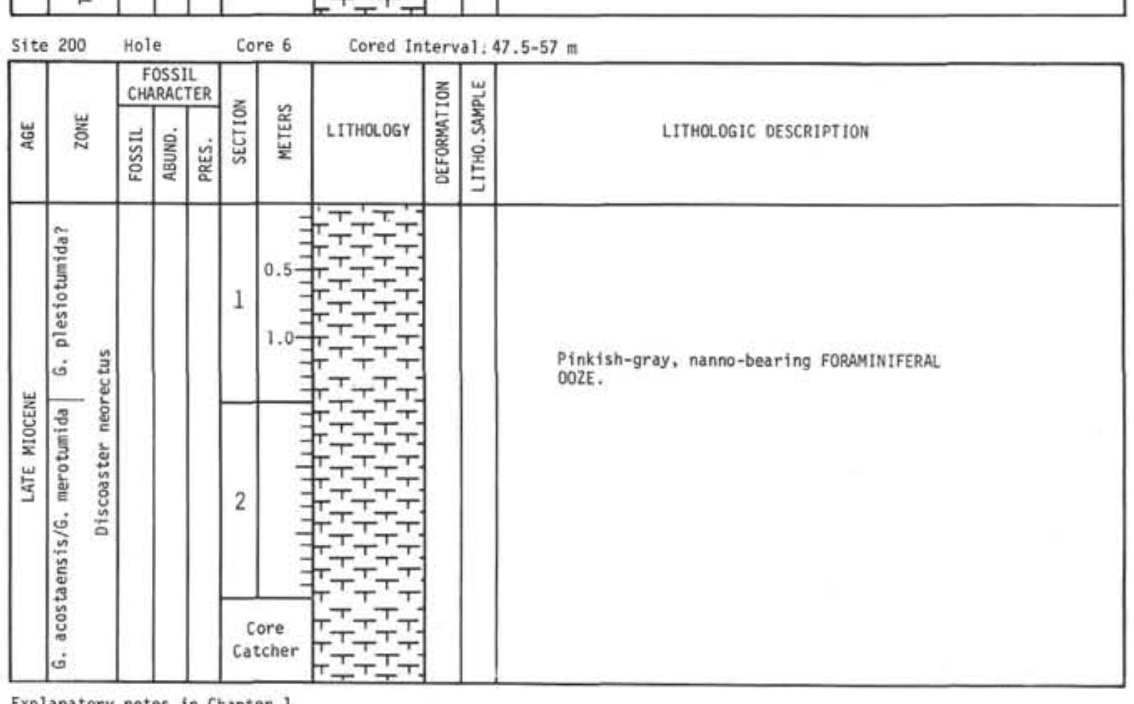

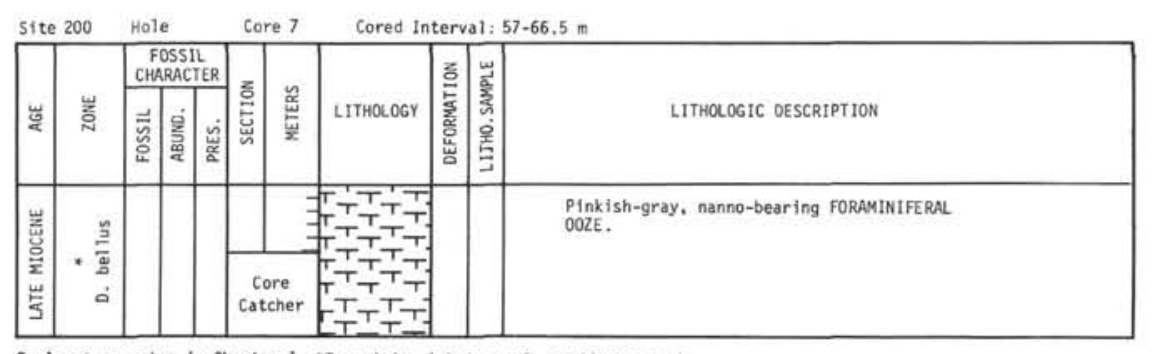

Explanatory notes in Chapter 1 "Transitional between 6 . continuosa and
G. acostaensis/6. nerotumida Zones

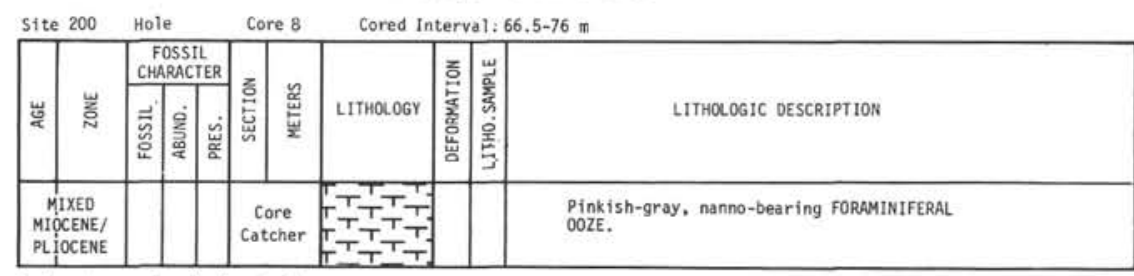

Explanatory notes in Chapter 1 


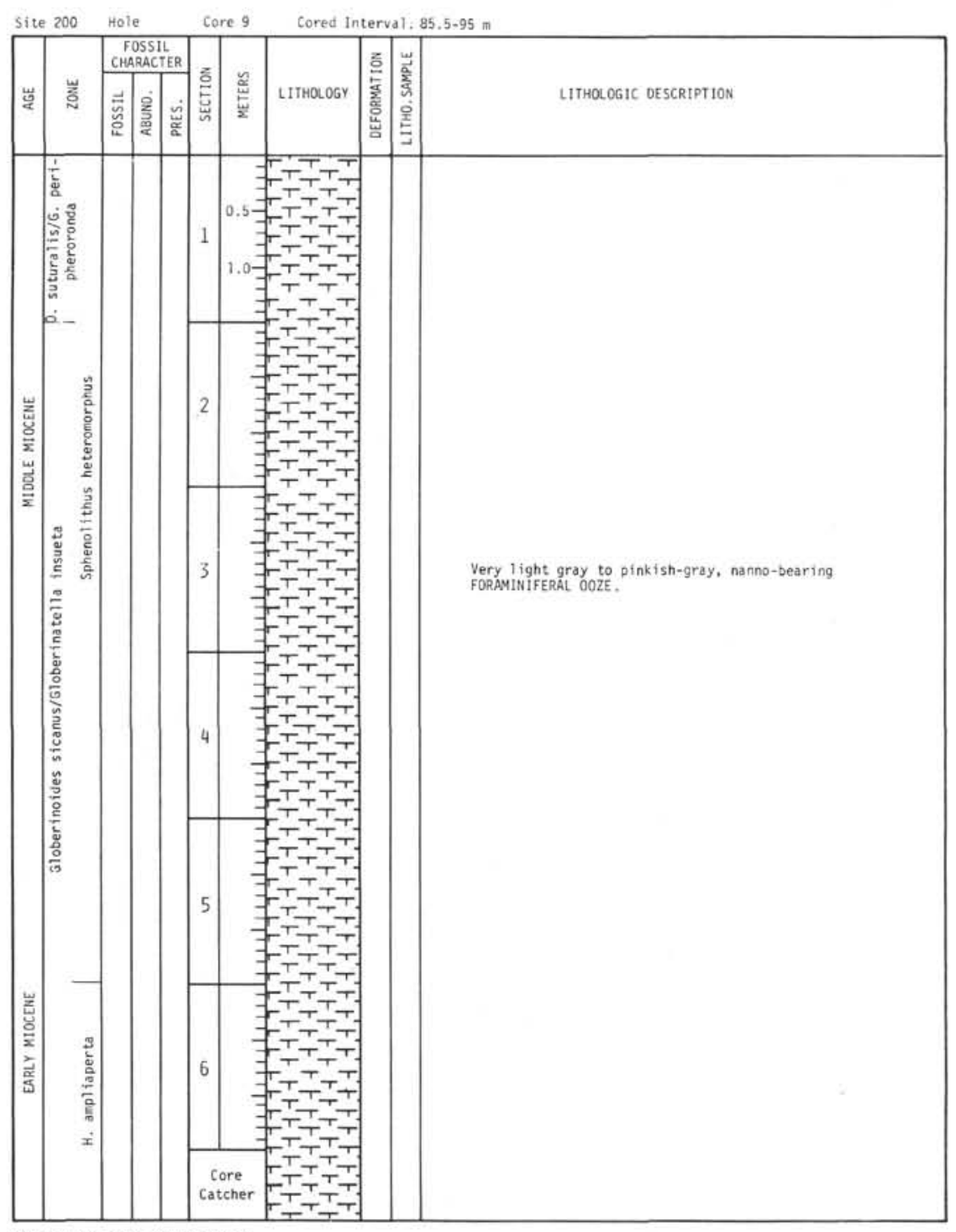

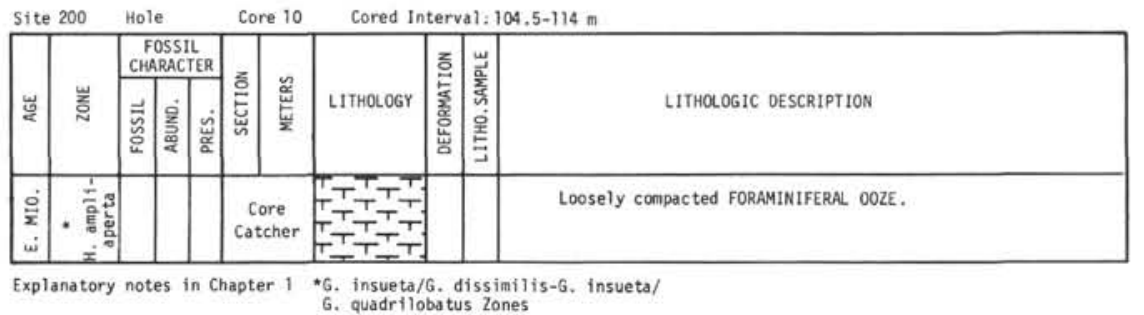

